University of South Carolina

Scholar Commons

Faculty Publications

History, Department of

Summer 7-1-1987

\title{
Program Development in Public History: A Look to the Future
}

Michael C. Scardaville

University of South Carolina - Columbia, mscardaville@sc.edu

Follow this and additional works at: https://scholarcommons.sc.edu/hist_facpub

Part of the History Commons

\section{Publication Info}

Published in Public Historian, Volume 9, Issue 3, Summer 1987, pages 163-170.

http://ucpressjournals.com/journal.asp?j=tph

(c) 1987 by University of California Press

This Article is brought to you by the History, Department of at Scholar Commons. It has been accepted for inclusion in Faculty Publications by an authorized administrator of Scholar Commons. For more information, please contact digres@mailbox.sc.edu. 


\title{
Program Development in Public History: A Look to the Future
}

\author{
Michael C. SCARDaville
}

Michael C. Scardaville, head of the applied history program at University of South Carolina, former chair of the National Council on Public History, and also a partner in a private consulting firm, argues that the future calls for a blending of the best of the traditional historical skills and the newer, more marketable skills pioneered by public history courses. He also suggests the importance of maintaining a balance between generalist and specialist programs and providing continuing education for both practicing public historians and their teaching colleagues.

The establishment of public and applied history programs at the University of South Carolina, the University of California at Santa Barbara, and Carnegie-Mellon University in 1975 marked the beginning of the public history training movement in the United States. Although the public historical profession dates back to the late nineteenth and early twentieth centuries, history departments did not systematically begin to train their students for nonacademic careers until the job crisis of the 1970s. The prospects of "alternative careers" and enhanced graduate enrollments were enough to justify the existence of public history offerings to even the most skeptical academic historians.

Critical developments have taken place as public history programs enter their second decade. The organizing of the National Council on Public History in 1979 promoted the establishment of public history training at the undergraduate and graduate levels. By 1985, over one hundred universities and colleges in the United States claimed to offer either individual courses or fully developed programs in historic preservation, cultural resource management, museum studies, community history, editing and publishing, archival management, and public policy and business analysis. ${ }^{1}$

1. National Council on Public History, Public History Education in America: A Guide (Morgantown, W.V., 1986). 
Impressive as this apparent success has been, much of the expansion in public history training was achieved without sufficient introspection or a full understanding of the issues and complexities of such training. Focusing on the immediate concerns of establishing formal programs and courses, history departments paid little attention to the rationale and philosophy of public history, a frequently voiced criticism at the NEHsupported "Teaching Public History" summer institute sponsored by the National Council on Public History in 1984.

The intent of this essay is to discuss the direction of public history training in the next decade by posing several interrelated issues which history departments most likely will confront when establishing or reviewing public history curricula. While not ignoring the mechanics of program development, the profession also should raise the level of discussion above these "nuts and bolts" concerns and seek an integrative and conceptual approach to public history training.

Discussion of common issues and philosophy should not be confused with a search for a uniform curriculum. One lesson of the past ten years is that there is no model public history program, no absolute standard against which training in the field can be measured. Programs and courses reflect a variety of institutional, financial, personnel, and community factors, and the most successful curricula are those that make most effective use of the varied resources. Uniting the diverse public history offerings is a need to establish a philosophical rationale. No longer is it sufficient to justify public history in strictly market-related terms. With apprehension about the job crisis likely to subside in the next ten years, public historians should be prepared to provide sound intellectual justification for training in this field.

Often lacking in the discussion of public history curriculum development is an attempt to identify the type of historian the department and profession wish to produce. Instead, the major concern typically centers on how students can find employment, an approach which fosters the "careerism" that still dominates the mind set of many students and faculty. As a result, departments generally concentrate on developing courses and programs that will enhance the job prospects of their students. Programs have been proposed that offer nothing more than a stitching together of "skills" courses that are in demand in the marketplace. While undoubtedly successful in fulfilling its employment mission, this approach to public history curriculum development has sacrificed a larger concern for the type of historian deemed most suitable for work in the nonacademic sector. The discussion of this question, however, might lead to a broader, integrative approach that can begin to provide a long-needed philosophical rationale to training in public history.

Do departments intend to train public historians-this new creatureor do they aim to create a more broadly trained historian? In retrospect, it seems that much of the talk about training this new type of historian has 
been prejudicial to the immediate acceptance and long-term prospects of the public history movement. It alienated many historians who had been working in various public historical fields even before the advent of the term or the academic training programs associated with it. The push to create a new type of historian in these programs erroneously suggested that public historians were somehow different, and therefore required substantially different training from more traditionally oriented historians. While helpful in raising consciousness and enabling administrators to justify these new programs, the emphasis on producing a new breed of historian unintentionally has created artificial barriers between academic and public historians and among public historians themselves. The profession needs to reexamine the type of historian these public history programs should be training, a process that might provide a more integrative and less divisive answer.

To assist in this endeavor, departments can discuss four issues inherent in all public history programs, regardless of orientation or level. No one program can offer all the training necessary for work in the nonacademic, or even academic, sector. Difficult decisions and compromises are at the heart of curriculum development. What is retained and what is excluded constitute an important philosophical statement about the nature of historical training and the type of historian it will produce.

\section{Relationship between Public History and Traditional History}

It is critical to maintain a balance between training in public historical skills and the traditional skills of the discipline. Techniques and methods do not in themselves constitute public history. The completion of National Register forms, the installation of an exhibit, and the processing of manuscripts are skills demanded of historians working in the public sector, but historical skills and knowledge are essential as well. Public historians need rigorous training in the historical research process, the analysis and synthesis of historical data, and the methods of communicating research findings. Through readings courses, research seminars, and other subject area courses, they should develop the ability to establish historical context and perspective in order to produce the most professional National Register nomination, museum exhibit, or archival finding aid. A poorly documented historic district does not meet professional standards in either the public or academic sectors even if the forms have been completed correctly. A well-designed and crafted material culture exhibit is inadequate if the audience cannot place the objects in a broader framework. The retention and processing of government records suffer if the archivist is unable to evaluate historical evidence or is unaware of research trends in different subject areas.

A 1980 study sponsored jointly by the National Council on Public His- 
tory and the American Historical Association underscores the centrality of traditional historical skills to public history. Over 2,300 public historians noted that research and communication (writing and speaking) were the most essential skills demanded on their jobs. While the study showed the importance of a variety of technical skills, the respondents believed that the traditional skills of the profession constituted the core of their public sector work. ${ }^{2}$ Most public historians would further acknowledge that National Register nominations and material culture exhibits represent nothing more than different forms of publication, ones which require research and communication standards comparable to academic norms.

Traditional historical skills are applicable in public history work, but historians working in or for preservation agencies, archives, museums, and government and business offices also should learn necessary technical skills as part of their academic training program. The demands of the marketplace cannot be arrogantly ignored, for employers of public historians expect some level of technical proficiency in their newly hired employees. Introduction to the preservation process, nonprofit financial planning and budgeting, and manuscripts conservation-each forms an essential component of public history training. In addition, students should stay abreast of the latest technical developments in the public historical fields, most notably in computer applications and advancements in conservation.

One goal of public history curriculum development is to offer a balance between technical and traditional historical skills. The publication of training program guidelines by professional organizations, however, makes it difficult to seek and sustain this balance. Within the last five years, the American Association for State and Local History, the Society of American Archivists, and the National Council on Preservation Education have published guidelines in an effort to achieve standardization in public history training. Drawn up in part as a response to the expansion of public history programs, they focus on skills required for employment in historical administration, archives, museums, and historic preservation. Scant attention is paid to the importance of communication and research abilities or to developing the subject area expertise needed to provide context. By stressing technical ability at the expense of historical (or any other subject area) expertise, the guidelines, were they formally adopted by university training programs and historical agencies, would likely cause an imbalance between the two skills areas. Alternatively, they could lead to an unjustifiable expansion in the number of credit hours necessary to accommodate the demands of history departments and the various historical and professional organizations.

2. National Council on Public History and American Historical Association, Survey of Historical Profession: Public Historians, 1980-81, Summary Report (Washington, D.C., 1981), 11-13. 


\section{Relationship between Generalist and Specialist Programs}

It is critical to maintain a balance between general training in a variety of public historical fields and specialized offerings in particular areas. This necessary balance can be difficult to maintain, however, particularly if the program offers strong subject area components as well.

The relative balance in public history generally satisfies the needs of employers who tend to require skills in specific areas. A state archivist would not deem one course in archival administration sufficient training for employment in the agency. An overview of historic preservation without intensive work in architectural history and preservation planning would not satisfy the requirements of organizations seeking a well-trained cultural resource specialist. At least two, and even more, courses, as well as an internship in one public history field, often constitute the minimum requirements for employment in good positions.

Yet a purely focused approach to public history training encourages the fragmentation of the field, a problem that has beset the academic profession and has led to its increasing insularity and isolation from larger historical issues and concerns. While specialization has its merits in the public sector, it increases isolation among the public historical fields. In addition, specialization does not address the reality of working conditions in many public historical environments. While historians in larger institutions are able to concentrate on either archival, preservation, or museum matters, those in smaller agencies and organizations (both historical and nonhistorical) find themselves in need of a variety of public historical skills.

One way for programs to strike a balance in public history training is to offer core courses in specialized areas, such as museum studies, community history, or policy analysis, and to build a more generalist approach through the use of electives. Such flexibility and program depth can be accomplished only where there are sufficient institutional and community resources, including the ability to employ practicing public historians as teaching faculty.

\section{Relationship between Historical and Multidisciplinary Training}

It is critical to develop a multidisciplinary approach to public history training. This approach enables history programs to build upon other university resources and allows public historians to cultivate an essential awareness of how other disciplines treat and study similar topics. Depending on the field, public historians often work with, among others, professional architects, architectural historians, anthropologists, archaeologists, folklorists, geographers, policy analysts, urban planners, economists, lawyers, and public administrators. Given the team-oriented nature of much 
of public historical research, historians are at a disadvantage if they cannot relate to other professions on their own terms or cannot understand their perspective.

The quality of historical research on a cultural resource project will suffer if the historian has not been involved in the development of the research design and cannot carry out the work plan in accordance with the needs of the archaeologists or architects. Full and proper integration of history in the policy process will not occur if the historian cannot communicate the research findings to other analysts and decisionmakers. The interpretive plan of a museum will offer a skewed view of the past if the historian does not adopt a broader, perhaps even an anthropological, approach. While historians should continue to extol the virtues of a historical understanding and promote the value of their discipline, public history programs must not embrace the confining notion that history offers the only valuable insight into research problems.

\section{Relationship between Terminal Degrees and Professional Development}

It is critical for public history programs to define curricula and students in broader terms. History departments should direct their energies not solely at the entry-level student, but also at those currently employed public historians who have no prior and sometimes inadequate historical and technical training. Departments should recognize their role and responsibility in enhancing the professional development of public historians, a process that, over time, will improve the practice of history throughout the public sector.

In addition to offering terminal degrees, programs could identify other ways to meet the needs of practicing public historians. The most creative and best endowed programs might sponsor certificate programs, summer programs, workshops, and forums adopted by other disciplines. Although the National Council on Public History has begun to hold professional development workshops before its annual conference, public history programs also should recognize their broader mission in the profession and develop and structure their curricula accordingly.

To be successful, professional development opportunities for practicing public historians must first gain support in the public sector. Private and public sector employers have a responsibility to enhance the professional development of their staffs by facilitating participation in universitysponsored educational endeavors and offering incentives for such involvement. A stronger alliance between academic training programs and the public sector should guide any consideration of curriculum development in public history. 
While the issues discussed above address some of the basic aspects of program development in public history and provide a framework for identifying the ideal type of historian, they still lack a justification or rationale. Underlining these major issues are several interrelated assumptions which should guide public history curriculum assessment and development.

Public history represents a necessary and valuable dimension in the way departments train professional historians. Public history does not exist merely to provide alternatives for the few available university positions. Work in the nonacademic sector should not be considered as a holding station for the "temporarily" unemployed academically oriented history student. Moreover, public historians should not be considered second-class citizens within the profession simply because traditionally trained historians do not understand what constitutes the professional responsibilities of archivists, policy analysts, curators, and preservationists. As has become evident in the last decade, public history is a viable field in its own right, making its own contribution to understanding the past and present, and, therefore, requires the same type of dedication and intellectual demands that often motivate students with ambitions of university teaching. Although market factors are always a consideration in developing any academic program, intellectual content and substance provide the foundation of public history programs. Without accepting these assumptions, training in public history becomes nothing more than an ad hoc response to the job crisis of the current generation.

Secondly, training in public history need not create a rigid division between academic and nonacademic historians. It should note, instead, that historians who are in public and private sector positions possess comparable historical skills but have developed additional techniques to deal with different audiences and a different work environment. Consequently, public history training should not minimize components of the undergraduate and graduate programs which assert a commonality of historical skills and background. All students should be expected to master sound research and methodological skills and analytical and writing abilities. As such, it is important to integrate public history programs into graduate and undergraduate programs as a whole. While recognizing special needs such as internships, these programs should not be conceived of as isolated, separate entities within departmental curricula.

In reviewing basic concerns and assumptions in public history curriculum development, it is essential not to dwell on the mechanics of program development until the philosophical issues have been raised and addressed. Departments should turn to course development, internship programs, and grant-funded student projects only after thoroughly understanding the kind of historian they intend to train. Ideally, public history programs should strive to create historians, not merely public historians, 
who have been exposed to broad areas of subject and technical expertise and who are equipped to handle the many skills demanded of historians today, regardless of place of employment.

This goal of training historians in the broadest possible terms also has implications for traditional graduate and undergraduate programs. Such programs should be raising the same issues and asking the same questions, a process which very well might lead to more cross-fertilization between public and traditional programs.

History departments need to overcome their historical amnesia and return to their late nineteenth-century mission of educating historians for both academic and public sector positions. They should try to recapture the notion that historians engage in service to the larger society, a belief that motivated the early generation of professional historians within the American Historical Association and in the graduate program at Columbia University.

Understandably, most public history programs today are well-defined, often separate entities within history departments. To define an area within an institution or a profession, it is often necessary to set it apart. The next decade, however, is the time to focus on the commonalities, not the differences, in historical training as part of building strong public and traditional history programs. Success in reaching this goal can be measured, in part, when public history training ceases to be such and enters the mainstream of graduate education in America. Public history will have arrived only when professional historians are no longer identified solely as history professors. 